\title{
Rare earth elements in gneiss regoliths in southern Minas Gerais, Brazil
}

\author{
Edilene Pereira Ferreira ${ }^{\circledR}$, Adriano Ribeiro Guerra, Antonio Carlos de Azevedo* (1)
}

Universidade de São Paulo/ESALQ - Depto. de Ciência do Solo, Av. Pádua Dias, 11 - 13418-900 - Piracicaba, SP Brasil.

*Corresponding author <aazevedo@usp.br>

Edited by: Paulo Cesar Sentelhas

Received July 09, 2019

Accepted December 01, 2019

\begin{abstract}
Regolith characterization in its entirety is particularly difficult in gneissic regoliths due to the heterogeneity of their rock structure. Rare earth elements (REE) are a useful tool in helping understand the evolution of regoliths. This study relates the mineralogy and weathering indexes of three gneisses regoliths (P1-leucocratic, P2-mesocratic and P3-melanocratic gneisses) to the distribution of REE at depth. In soil, clay activity, iron and manganese oxides, $\mathrm{CaO}, \mathrm{SiO}_{2}, \mathrm{P}_{2} \mathrm{O}_{5}, \mathrm{TiO}_{2}, \mathrm{Fe}_{2} \mathrm{O}_{3}$, and $\mathrm{MgO}$ showed high positive correlation with REE. The absolute content of REE was enriched in mafic minerals. At the interface between the soil and saprolite, the sum of absolute REE content was greater in soil than in saprolite in $\mathrm{P} 1$, while the opposite pattern was found in $\mathrm{P} 2$ and $\mathrm{P} 3$. The sums of absolute REE in the whole profiles did not overlap between P1, P2 and P3, and the absolute concentration of Gadolinium (Gd) differentiated the three gneisses in all and every horizon/layer of their regoliths without overlapping values. Normalized REE content was greater in the subsurface of P1 due to Eu content in plagioclase, and fractionation had less variation when estimated by Light REE / Heavy REE (LREE/HREE) than by $\mathrm{La} / \mathrm{Yb}$, since the variation in REE is great in gneisses (due to the segregation of minerals into bands), and had low levels of association with the Chemical Index of Alteration (CIA) and the Weathering Index of Parker (WIP).
\end{abstract}

Keywords: saprolite, weathering, pedogenesis

\section{Introduction}

Rare earth elements (REE) are the set of 14 chemical elements with atomic numbers between 57 and 71 and are frequently grouped into light REE (LREE: La, Ce, $\mathrm{Pr}, \mathrm{Nd}, \mathrm{Sm}, \mathrm{Eu}$; Lanthanium, Cerium, Praseodymium, Neodymium, Samarium, Europium) and heavy REE (HREE: Gd, Tb, Dy, Ho, Er, Tm, Yb, Lu; Gadolinium, Terbium, Dysprosium, Holmium, Erbium, Thulium, Ytterbium, Lutetium). The REE can be environmental tracers and are therefore of interest to weathering studies (Aide and Smith-Aide, 2003; Aubert et al., 2004; Laveuf et al., 2008; Laveuf and Cornu, 2009). The REE content in regoliths strongly depends on the type of parent material, which is their primary source (Yamasaki et al., 2001; Hu et al., 2006). Since REE have similar atomic properties, their distribution along the regolith can help to understand the weathering and pedogenic processes, their stages of development and even the contribution of an external source of materials (alloctonism) ( $\mathrm{Hu}$ et al., 2006; Jin et al., 2017; Laveuf and Cornu, 2009; Yusoff et al., 2013). Fractionation patterns of LREE and HREE also mimic the pattern of plant nutrients $(\mathrm{Hu}$ et al., 2006; Ma et al., 2007; Laveuf and Cornu, 2009; Yusoff et al., 2013; Sadeghi et al., 2013). The soil-saprolite interface is crucial as a nutrient source for organisms, filtration of water, as well as the boundary between the dominance of weathering and pedogenic processes (Santos et al., $2017,2018 b)$. In the field, the morphological distinction between soil and saprolite is not always clear, particularly in profiles developed from metamorphic, banded rocks (Santos et al., 2019b). The superimposition of parent rock heterogeneity and differentiation by weathering and pedogenetic processes imposes an extra difficulty on interpreting contrasting distributions of elements throughout the profile, not to mention the cases in which alloctonous material was added (Price and Velbel, 2003). Santos et al. (2019a) compared the soil-saprolite boundary assigned in the field by pedologists with the boundary assigned by the highest contrast in the chemical and physical properties in 25 regolith profiles. The greatest discrepancy was found in profiles derived from metamorphic, banded rocks.

Since interpretation of the distribution pattern of chemical elements throughout the regolith profile is particularly complex in rocks with heterogeneous structure, such as gneiss (Santos et al., 2019b), the present study adds to previous work done in the northeast of Brazil (Silva et al., 2001; Santos et al., 2019a) by characterizing REE distributions along three regolith profiles with the contrasting content of mafic minerals, namely, leuco-, meso- and melanocratic gneisses. The Passos, MG region offers a unique opportunity to investigate this set of regolith profiles weathered under similar conditions. The specific objectives were: (1) relate mineralogy assemblage and mineral weathering to the REE content in each profile; (2) determine the absolute REE content, calculate the normalization, anomalies and fractionation of REE and relate them to weathering and pedogenesis; and (3) relate the REE patterns to the boundaries between soil-saprolite and saprolite-rock.

\section{Materials and Methods}

\section{Study site, sampling and soil classification}

Regolithic profiles derived from gneisses were described and collected from the field in Passos and Itaú de Minas, both municipalities in the state of Minas 
Gerais (MG), Brazil (Figure 1A, B and C). The climate in the region was dominantly humid subtropical with dry winters and hot summers (Cwa) according to the Köppen classification. Precipitation in the region ranges from 1600 to $1900 \mathrm{~mm}$ (Alvares et al., 2014) and original vegetation was the Brazilian Cerrado (savannah) and the Deciduous Forest (Ministério das Minas e Energia, 1983). The locations were: P1 $\left(20^{\circ} 46^{\prime} 20.0^{\prime \prime} \mathrm{S}, 46^{\circ} 45^{\prime} 07.8^{\prime \prime} \mathrm{W}\right.$, altitude of $770 \mathrm{~m}$, precipitation $1475 \mathrm{~mm}$, temperatures $\left.10.2^{\circ} \mathrm{C}_{\text {min }}, 23.1{ }^{\circ} \mathrm{C}_{\text {average }} 28.1^{\circ} \mathrm{C}_{\text {max }}\right) ; \mathrm{P} 2\left(20^{\circ} 52^{\prime} 45.7^{\prime \prime} \mathrm{S}\right.$, $46^{\circ} 35^{\prime} 53.6^{\prime \prime} \mathrm{W}$, altitude of $1050 \mathrm{~m}$, precipitation 1423 $\mathrm{mm}$, temperatures $9.9{ }^{\circ} \mathrm{C}_{\min }, 23{ }^{\circ} \mathrm{C}_{\text {average' }} 28.2{ }^{\circ} \mathrm{C}_{\max }$ ); P3 $\left(20^{\circ} 40^{\prime} 21.4^{\prime \prime} \mathrm{S}, 46^{\circ} 32^{\prime} 20.5^{\prime \prime} \mathrm{W}\right.$, of altitude $760 \mathrm{~m}$, precipitation $1423 \mathrm{~mm}$, temperatures $9.9{ }^{\circ} \mathrm{C}_{\min ,} 23$ ${ }^{\circ} \mathrm{C}_{\text {average }}, 28.2{ }^{\circ} \mathrm{C}_{\max }$ ). The soils were classified according to the Brazilian System of Soil Classification (Santos et al., 2018a) into: a) P1-Argissolo Acinzentado Eutrófico típico; b) P2 - Argissolo Vermelho Amarelo Distrófico típico; c) P3 - Argissolo Vermelho Eutrófico típico; the World Reference Base (WRB) (FAO, 2015) into: P1 - Skeletic Lixisol, P2 - Haplic Acrisol and P3 - Haplic Lixisol; and the saprolites were classified according to the Subsolum Reference Groups (SRG) from Juilleret et al. (2016): a) P1 - Skeletic Lixisol over Haplic
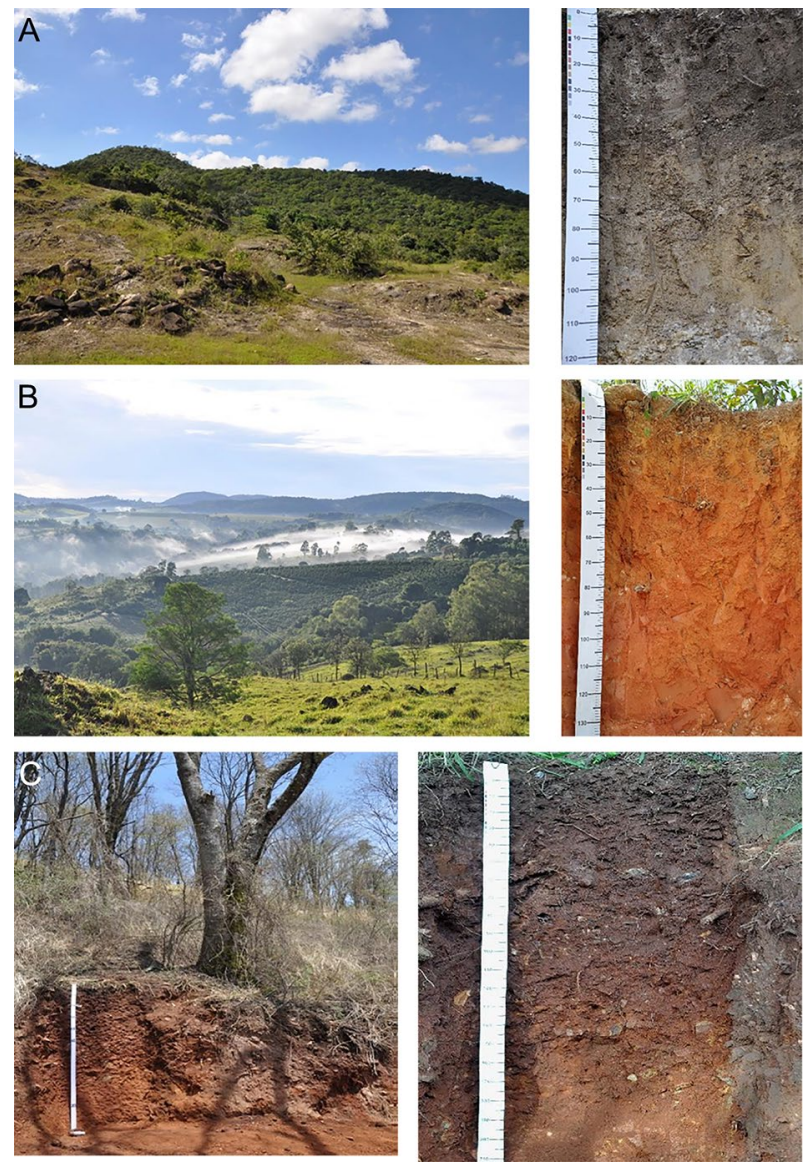

Figure 1 - Relief, vegetation and sampling pit of profile A) P1, B) P2 and C) P3.
Saprolite (Arenic, Clinibedic, Skeletic) [Gneissic]; b) P2 - Haplic Acrisol over Haplic Saprolite (Siltic, Clinibedic) [Gneissic]; c) P3 - Haplic Lixisol over Haplic Saprolite (Siltic, Skeletic) [Gneissic]. These profiles were chosen in order to achieve the objective of the study (compare REE in regolith with increasing mafic minerals), and although the three profiles had similar pedogenesis (all three are Argisols under the Brazilian Soil Classification System), it was not possible find profiles with a similar degree of pedogenesis, as can be inferred a priori from the depth and number of horizons/layers, and later by the weathering indexes.

The region in the municipality of Passos belongs to the Geomorphological Unit the Canastra Plateaus. The predominant relief consists of large hills linked to planed tops with convex and ramped slopes in the incipient phase of dissection. To a lesser extent, more dissected reliefs with strands of greater slope can be found on the edge of slopes of plateaus of the river Alto Rio Grande. As regards to geology, the profiles were derived from rocks belonging to the Campos Gerais Complex, which consists of lithologies reworked by tectonic events associated to the crustal dynamics, associated with the Transamazonic Cycle (1650 million years). It has milonite-gneisses, fillites, and cataclastic granitic rocks. This rock often contains both amphibolitic and ultramfic bodies. The lithologies extend from the north of the town of Alfenas, in the state of Minas Gerais State to São Sebastião do Paraiso, also in Minas Gerais (Ministério das Minas e Energia, 1983).

\section{Laboratory methods}

The analyses of the sorptive complex of the soil were carried out according to Teixeira (2017). The contents of $\mathrm{Fe}$ and $\mathrm{Mn}$ in the extracts of Na-dithionitecitrate-bicarbonate (Mehra and Jackson, 1960) and ammonium oxalate acid (McKeague and Day, 1966) were determined by atomic absorption spectrometry.

To determine the total content of elements, including the REE content, the samples of soil, saprolite and rock were air dried, homogenized and milled to particle size $<100 \mu \mathrm{m}$. Subsamples $(0.25 \mathrm{~g}$ for rock and saprolite; $0.1 \mathrm{~g}$ for soil samples) were subjected to digestion by triacid attack $\left(\mathrm{HNO}_{3}, \mathrm{HClO}_{4}\right.$ and $\left.\mathrm{HF}\right)$ with heating and dissolution of the residue with $\mathrm{HCl}$. The REE elements were determined by mass spectrometry with inductively coupled plasma (ICP-MS) in the acid extracts, according to Eberl and Smith (2009). The samples were part of a batch of 74 samples, plus 5 replications of Standard Material OREAS25A-4A, 5 replications of Standard Material 45E and 3 blanks. Blanks were all below the detection limits for all elements reported here. The determination of element content in standards were below $5 \%$ error for all elements, except for Fe $(6.5 \%)$, $\mathrm{La}(5.6 \%)$ and $\mathrm{Ce}(17.8 \%)$. The detection limit was 0.1 $\mathrm{mg} \mathrm{kg}{ }^{-1}$ except $\mathrm{Ce}$ which was $0.02 \mathrm{mg} \mathrm{kg}^{-1}$. In addition to the REEs, the total content of $\mathrm{Al}, \mathrm{Ca}, \mathrm{Fe}, \mathrm{K}, \mathrm{Mg}, \mathrm{Na}, \mathrm{P}$, $\mathrm{Ti}$ was also determined in these samples. 
Mineralogical composition was identified by optical microscopy on thin sections under a Zeiss petrographic microscope. Color photomicrographs (RGB) were taken using transmitted plane-polarized light (TPPL) and transmitted cross-polarized light (TXPL). The magnifications used were 12.5X,25X, 100X, 200X and 400X. The scale and magnifications were indicated on photomicrographs. Primary and secondary minerals were identified according to Kerr (1977) and Delvigne (1998). Silicate minerals in selected samples and fractions were identified by x-ray diffractometry in Rigaku Miniflex II using $\mathrm{Cu}$ K-alpha radiation, $\mathrm{Ni}$ filter and graphite monochromator. The sand fraction was collected after dispersion with $\mathrm{NaOH}$ solution and wet sieving. The clay fraction was separated from silt and both were collected by siphoning. Prior to clay irradiation, carbonates, iron oxides and organic matter were eliminated. Diffraction patterns were interpreted according to Jackson (1975), Moore and Reynolds (1997) and the Crystallographic Open Database (COD) (Grazulis et al., 2009)

\section{Calculations}

The total dissolution results were used to calculate the weathering index of Parker (WIP, Equation 1), which is more suitable for heterogeneous materials (Price and Velbel, 2003; Schucknecht et al., 2012), particularly felsic regoliths (Price and Velbel, 2003).

$\mathrm{WIP}=\left(2 * \mathrm{Na}_{2} \mathrm{O} / 0.35\right)+(\mathrm{MgO} / 0.9)+\left(2 * \mathrm{~K}_{2} \mathrm{O} / 0.25\right)+$
$(\mathrm{CaO} / 0.7)$

The chemical index of alteration (CIA, Equation 2) was also computed (Nesbitt and Young, 1982). The CIA is commonly applied when studying the chemical mobility of elements (Sanematsu et al., 2015; Price and Velbel, 2003).

$\mathrm{CIA}=\left[\mathrm{Al}_{2} \mathrm{O}_{3} /\left(\mathrm{Al}_{2} \mathrm{O}_{3}+\mathrm{Na}_{2} \mathrm{O}+\mathrm{CaO}+\mathrm{K}_{2} \mathrm{O}\right)\right] \times 100$

To better study the REE distribution along regolith profiles it is advisable to normalize the data against a reference material. It can be done using an external reference such as the Upper Continental Crust - UCC (Taylor and McLennan, 1985), or an internal reference such as the parent material of the profile (Henderson, 1984; Laveuf and Cornu, 2009). We choose to present here the parent material normalization because the UCC normalization resulted in enrichment factors of up to 16 times for P2 and P3, contrasting with the enrichment factor of $\mathrm{P} 1$ of only 2.5 . This was so because melanocratic (P3) and mesocratic (P2) gneisses are enriched in REE as compared to UCC (Taylor and McLennan, 1985), due to the presence of REE rich minerals such as biotite, magnetite, and hornblende (Condie et al., 1995). Therefore, since one of the objectives of this study was to characterize the pattern of REE distribution along profiles with similar pedogenesis (all three are Argisols in the Brazilian Soil Classification System) but with an increase in mafic minerals (from leuco- to melanocratic) the parent material normalization was better suited. Whatsmore, in fact, the enrichment factors decreased from 16 to 8 in $\mathrm{P} 2$ and from 16 to 1.20 in $\mathrm{P} 3$, while in $\mathrm{P} 1$ it remained close to 2.50. This was so because the UCC values are more similar to those of acid magmas. Aluminum (Al) is a conservative element and was used as a normalization element. Normalization was calculated using Equation 3:

normalization $=\left(\mathrm{REE}_{\text {sample }} / \mathrm{Al}_{\text {sample }}\right) /\left(\mathrm{REE}_{\text {rock }} / \mathrm{Al}_{\text {rock }}\right)$

where a normalized value $>1$ indicates the element enrichment and a normalized value $<1$, depletion. Anomalies were calculated by

$$
\left(\mathrm{Ce}_{\mathrm{N}} /\left(\mathrm{La}_{\mathrm{N}}+\mathrm{Pr}_{\mathrm{N}}\right) * 0.5\right.
$$

For Ce and

$\left(\mathrm{Eu}_{\mathrm{N}} /\left(\mathrm{Sm}_{\mathrm{N}}+\mathrm{Gd}_{\mathrm{N}}\right) * 0.5\right.$

For $\mathrm{Eu}$, where $\mathrm{Ce}_{\mathrm{N}}, \mathrm{La}_{\mathrm{N}}, \operatorname{Pr}_{\mathrm{N}} \mathrm{Eu}_{\mathrm{N}}, \mathrm{Sm}_{\mathrm{N}}$ and $\mathrm{Gd}_{\mathrm{N}}$ are the normalized values for these elements.

The ratio LREE/HREE (fractionation) was also calculated. The matrix of the Pearson correlation coefficient between the absolute (non-normalized) REE concentration and certain soil attributes was determined by the analysis software from xl-stat.

\section{Results and Discussion}

\section{Mineralogy of regolith-rock profiles The illite-sericite problem}

A 2:1 phyllosilicate was detected by both optical microscopy and XRD diffractometry (not shown). This phyllosilicate maintained fixed (001) spacing despite treatments to expand and collapse it. Therefore, it may be referred to as a mineral belonging to the illite group. However, in P1 and P2, evidence of sericitization of feldspars (a mineral common to them both, Figures 2A, B and 3A, B), which may occur during granite metamorphism to gneiss, was observed through the optical microscopy (e.g., Figure 2C and D, Figure 3C and D). Sericitization produces sericite, which is a petrographic term used to indicate a highly birefringent, fine-grained, mica-type mineral observable under the optical microscope, and Eberl et al., (1987) reported it with a layer charge close to -1.0 equivalent per $\mathrm{O}_{10}(\mathrm{OH})_{2}$. A number of authors propose sericite as an independent mineral (e.g. Inoue, 1995) while others propose a mineral of the illite group (e.g. Eberl et al., 1987; Meunier and Velde, 2010). In their "Illite" book, Meunier and Velde (2010) implied that sericite would be an illite-type mineral originated from hydrothermal metamorphism. The identification and characterization of illites (and by extension, sericite) is not settled even after the mathematical modeling of XRD scans (Meunier and Velde, 2010). In P1 and P2, this 2:1 phyllosilicate may be a sericite or an illite formed by the weathering 
of micas and feldspars, or a mixture of both minerals. Because of this, XRD scans could not inform which is the case, especially so due to the fact that criteria to distinguish them are not settled. Since the focus of this paper was not to address this unexpected issue, we will refer to this 2:1 phyllosilicate as "sericite" where it can be positively identified (by its high birefringence under optical microscope), as "illite (sericite?)" where we suppose it can or cannot be sericite (our data were not sufficient to be sure) and as "illite" when found in the P3 profile (where sericitization was not observed).

\section{Regolith profile on leucocratic gneiss (P1)}

The parent material of $\mathrm{P} 1$ had a gneissic structure and a granoblastic texture. Quartz, feldspars (microcline and plagioclase) and a small amount of biotite (Figure 2A and $\mathrm{B}$ ) were identified. The $\mathrm{RCr} 2$ layer sample showed sericite in intersticies (Figure 2C), as well as the alteration of plagioclases into illite (sericite) in $\mathrm{Cr} 2$, destroying their shape completely (Figure 2D). Formation of kaolinite from biotite (Figure 2E) occurred at $\mathrm{Cr} 1$, similar to the report of Meunier and Velde (1982), while the K-feldspar remained intact. On horizon $\mathrm{Cr} 1$, oxidation of biotite and the last remains of rock structure were observed (Figure 2E), while on both $\mathrm{Cr} 1$ and $\mathrm{Cr} 2$, optical and XRD data (not shown) indicated the formation of kaolinite. Plagioclase weathering reached its maximum at the $\mathrm{C}$
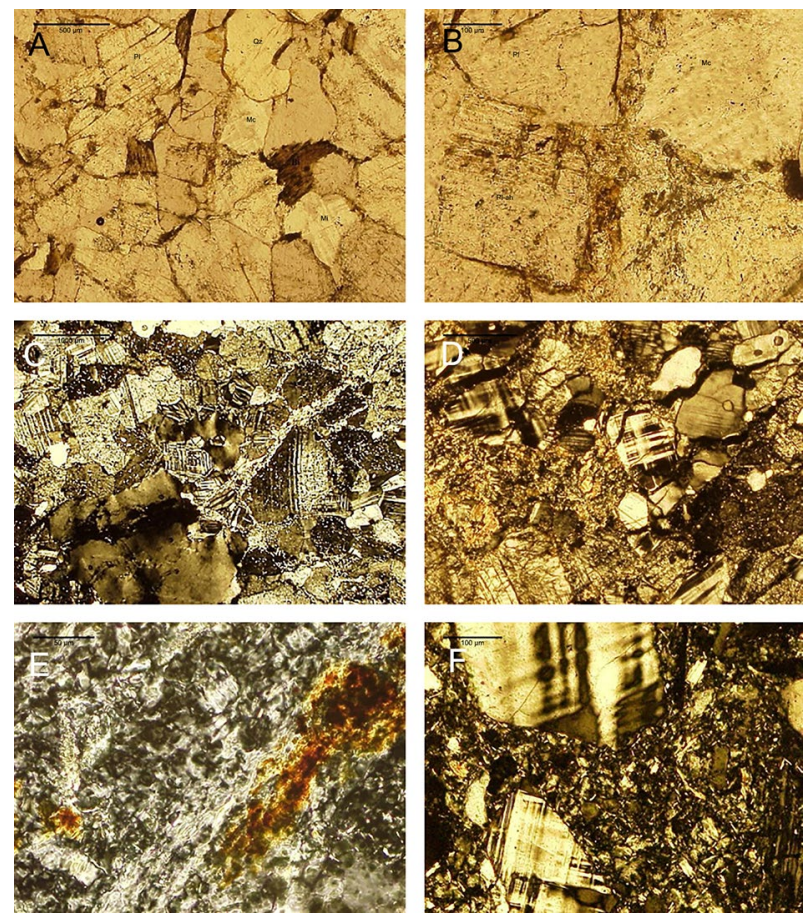

Figure 2 - Photomicrographs of the P1 profile. A) R layer, TPPL, 25X. B) R layer, TPPL, 100X C) RC layer, TXPL, 12.5X, D) CR2 horizon, TXPL, 25X E) CR1 horizon, TXPL, 200X, F) C horizon, TXPL, 100X. Transmitted plane-polarized light = TPPL; Transmitted cross-polarized light $=$ TXPL. horizon, barely being identified by x-ray diffractometry (not shown), although potassium feldspar remained (Figure 2F). The K-feldspars were found even in the Bt2 horizon, where secondary minerals grew into their broken cleavages. In the Bt 1 horizon there was an intense presence of clay, but potassium feldspars were still observed amid the kaolinitic-illitic (sericitic?) mass of the Bt1A and A horizons. The K-feldspars and illite (sericite?) dominated the silt fraction of the whole profile, together with a minor amount of kaolinite, while the clay fraction was dominated by kaolinite, illite, and gibbsite.

\section{Regolith profile on mesocratic gneiss (P2)}

The P2 had a gneissic rock structure and a granulitic texture, and was composed predominantly of quartz, K-feldspar, plagioclase and well-oriented biotite bundles (Figure 3A). Plagioclase grains showed frequent epidote inclusions (Figure 3B), and sericite was present in intergranular spaces (Figure $3 \mathrm{C}$ ). Horizon $\mathrm{Cr} 1$ had a heterogeneous mass of oxidized biotitic bundles (Figure $3 \mathrm{D}$ ), weathered plagioclase and sericite (Figure $3 \mathrm{E}$ and F), and the inclusions of epidotes formed brownish spots. Unweathered biotite particles were already absent, and zones with partial or completely destroyed rock structure alternated with zones of pedoplasmation. The $\mathrm{Cr} 1 \mathrm{C}$ was a mixture of pedogenized portions with
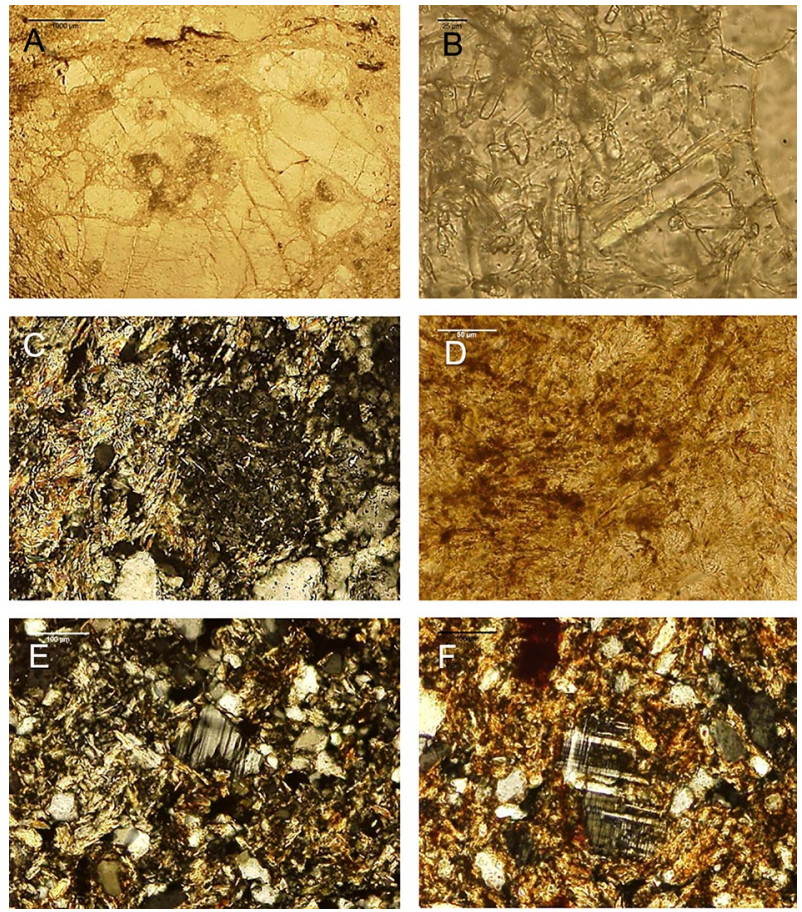

Figure 3 - Photomicrographs of the $P 2$ profile. A) R layer, TPPL, 12.5X. B) R layer, TPPL, 400X C) R layer, TXPL, 100X, D) CR horizon, TPPL, 200X E) CRC horizon, TXPL, 100X, F) C horizon, TXPL, 100X. Transmitted plane-polarized light = TPPL; Transmitted cross-polarized light $=$ TXPL. 
quartz-oxides-kaolinite-illite (sericite?) composition and saprolitic fragments of quartz and weathered K-feldspar (Figure 3E). The rock structure was partly identifiable only in saprolitic fragments. Plagioclase, if present, was insufficient to yield diffraction peaks. Mineralogy of horizons $\mathrm{C}$ and $\mathrm{CBt} 2$ were similar to $\mathrm{Cr} 1 \mathrm{C}$, with wellpreserved grains of K-feldspar, incipient aggregation and microvesicular and channel pores. They differed from each other in color. Horizon Bt had an oxidickaolinitic-illitic (sericitic?) matrix and the sand fraction consisted of quartz grains and K-feldspars in a dense arrangement. Porosity was determined largely by vesicles and channels. The A horizon had pseudomorphs of sericitized plagioclase, well-preserved biotite and intact K-feldspars, in addition to oxide coated grains of quartz distributed randomly on the kaolinitic-illitic (sericitic?) matrix. The unexpected increase in the type and amount of primary minerals in this horizon, together with the profile location in a steep position along the slope, strongly suggests addition of material from upslope sources.

\section{Regolith profile on melanocratic gneiss (P3)}

Rock from profile P3 had a gneissic structure and porphyritic-granoblastic texture, with great variability in metric distances, making its overall characterization very difficult. Mineralogy was quartz, hornblende, K-feldspar, magnetite, muscovite and garnet (Figure $4 \mathrm{~A}$ and $\mathrm{B}$ ). Hornblende was greenish-brown under polarized plane light (PPL) and a number of grains of magnetite showed a sharp outline due to manifestation of its habit (Figure 4A), and garnet porphyroblasts were present (Figure 4B). The $\mathrm{Cr}$ layer alternated felsic and mafic bands (Figure 4C), with the presence of oxidic microgranules (Figure 4D). Horizon C had traces of garnet and both weathered and well-preserved hornblende (Figure 4E). Weathered biotite flakes were immersed into an oxidized matrix, and grains of preserved and altered (pseudomorphs) hornblende were common. In horizons $\mathrm{B}$ and $\mathrm{A}$, hornblende, muscovite flakes and K-feldspar were present while in A infillings of alloctonous particles, airborned from an adjacent mining pit, were mixed into the soil by bioturbation (Figure 4F). The silt fraction of soil horizons of P3 had quartz, K-feldspars and hornblende, and a small content of kaolinite and mica. The XRD peaks of hornblende were particularly evident in the $\mathrm{C}$ and $\mathrm{BtC}$ horizons, and K-feldspar peaks were evident in all horizons. The clay fraction had kaolinite and illite.

\section{Absolute REE concentration}

Because of their mesocratic and melanocratic nature, respectively, primary minerals in P2 and P3 had greater LREE content than leucocratic P1, because P1 had a high content of quartz, a mineral that lacks REE (Compton et al., 2003). At the soil-saprolite transition in P1, the sum of REE content was greater in soil $151.35 \mathrm{mg}$ $\mathrm{kg}^{-1}$ in C) than in saprolite (34.43 $\mathrm{mg} \mathrm{kg}^{-1}$ in $\mathrm{Cr} 1$ ) and the
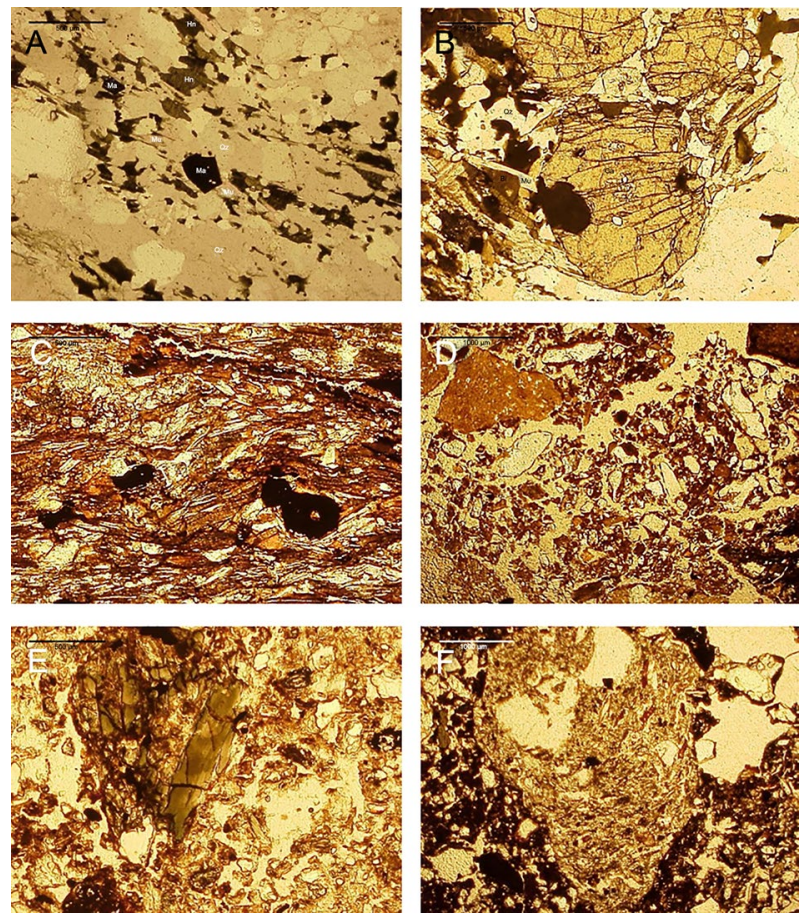

Figure 4 - Photomicrographs of the P3 profile. A) R layer, TPPL, 12.5X. B) R layer, TPPL, 25X C) RC layer, TPPL, 25X, D) RC layer, TXPL, 12.5X E) C2 horizon, TPPL, 25X, F) A horizon, TPPL, 12.5X. Transmitted plane-polarized light $=$ TPPL; Transmitted crosspolarized light $=$ TXPL.

opposite in $\mathrm{P} 2\left(171.84 \mathrm{mg} \mathrm{kg}^{-1}\right.$ in $\mathrm{C}$ and $191.1 \mathrm{mg} \mathrm{kg}^{-1}$ in $\mathrm{CRC}$ ) and P3 (346.0 mg kg-1 in C and $738 \mathrm{mg} \mathrm{kg}^{-1}$ in $\mathrm{Cr}$ ). The sum of REE increased from P1 towards P3 due to increases in the REE rich mafic minerals from leuco- to melanocratic gneiss (Table 1). The REE increased in the surface horizon of profile P3, particularly of $\mathrm{La}, \mathrm{Ce}, \mathrm{Pr}$, $\mathrm{Nd}$ and $\mathrm{Sm}$, attributable to the depositing of rock dust coming from adjacent mining activities. Additionally, in $\mathrm{P} 3$, in horizon $\mathrm{BtC}$, a great diversity of minerals including mica, hornblende, kaolinite, microcline and quartz, coincided with the increase of $\mathrm{Ce}$ in this horizon, while in the horizon $\mathrm{Cr}$, the increase in REE was due to the abundance of hornblende (Rollinson, 1993).

\section{Normalized REE concentration}

The normalization to parent material resulted, in general, in a depletion pattern (Figure 5). Enrichment was found in the deeper $\mathrm{Cr}^{\prime}$ s horizons. In $\mathrm{P} 2$, the $\mathrm{Cr} 2$ layer had enrichment that was extreme and reached almost a factor of 8.0. This suggests that $\mathrm{Cr} 2$ originated from a different band in the gneissic structure, since Cr1 was only slightly more enriched than the pedogenic horizons. On the other hand, near surface enrichment of LREE occurred in P2 because of the input of external material due to its position along the slope, as discussed before. Considering only the REE concentrations, the input of upslope material in P2 had a greater impact 
Table 1 - Content of rare earth elements of soil-saprolite profiles derived from gneisses in the southeastern region of Brazil.

\begin{tabular}{|c|c|c|c|c|c|c|c|c|c|c|c|c|c|c|c|c|}
\hline \multirow[b]{2}{*}{ Zone } & \multirow[b]{2}{*}{ Horizon/Layer } & \multirow[b]{2}{*}{ Depth } & \multicolumn{6}{|c|}{ Light Rare Earth Elements (LREE) } & \multicolumn{8}{|c|}{ Heavy Rare Earth Elements (HREE) } \\
\hline & & & $\mathrm{La}$ & $\mathrm{Ce}$ & $\mathrm{Pr}$ & $\mathrm{Nd}$ & $\mathrm{Sm}$ & $\mathrm{Eu}$ & $\mathrm{Gd}$ & $\mathrm{Tb}$ & Dy & $\mathrm{Ho}$ & $\mathrm{Er}$ & $\mathrm{Tm}$ & $\mathrm{Yb}$ & Lu \\
\hline & & $\mathrm{cm}$ & & & & & & & $-\mathrm{mg} \mathrm{kg}$ & & & & & & & \\
\hline \multicolumn{17}{|c|}{$\mathrm{P} 1$} \\
\hline Soil & A & $0-20$ & 4.3 & 9.3 & 0.7 & 3.3 & 0.9 & 0.1 & 0.6 & 0.1 & 0.7 & 0.1 & 0.4 & 0.1 & 0.4 & 0.1 \\
\hline Soil & Bt1A & $20-40$ & 4.8 & 13.5 & 0.9 & 2.8 & 0.8 & 0.1 & 0.7 & 0.1 & 0.7 & 0.1 & 0.5 & 0.1 & 0.4 & 0.1 \\
\hline Soil & Bt1 & $40-70$ & 6.6 & 13.6 & 1.1 & 4.6 & 0.9 & 0.1 & 0.6 & 0.1 & 0.9 & 0.1 & 0.5 & 0.1 & 0.5 & 0.1 \\
\hline Soil & $\mathrm{Bt} 2$ & $70-110$ & 8.9 & 11.3 & 1.9 & 7.0 & 1.3 & 0.4 & 1.0 & 0.2 & 1.0 & 0.2 & 0.6 & 0.1 & 0.8 & 0.1 \\
\hline Soil & C & $110-140$ & 12.6 & 15.9 & 3.0 & 11.2 & 2.0 & 0.7 & 1.8 & 0.3 & 1.4 & 0.3 & 1.0 & 0.2 & 0.8 & 0.1 \\
\hline Saprolithic layer & Cr1 & $140-220$ & 6.8 & 11.6 & 2.0 & 6.8 & 1.6 & 0.6 & 1.2 & 0.2 & 1.4 & 0.3 & 0.8 & 0.1 & 0.8 & 0.2 \\
\hline Saprolithic layer & $\mathrm{Cr} 2$ & $220-320$ & 7.7 & 13.7 & 2.2 & 8.7 & 1.8 & 0.4 & 1.6 & 0.2 & 1.2 & 0.2 & 0.7 & 0.1 & 0.7 & 0.1 \\
\hline Rock & $\mathrm{RCr} 2$ & 400 & 7.7 & 13.1 & 1.8 & 6.7 & 1.1 & 0.1 & 0.9 & 0.1 & 0.5 & 0.1 & 0.2 & 0.1 & 0.3 & 0.1 \\
\hline Rock & $\mathrm{R}$ & 500 & 6.2 & 11.4 & 1.5 & 5.7 & 1.7 & 0.2 & 1.3 & 0.3 & 2.2 & 0.5 & 1.5 & 0.3 & 1.6 & 0.2 \\
\hline \multicolumn{17}{|c|}{ P2 } \\
\hline Soil & A & $0-10$ & 51.2 & 124.4 & 8.0 & 28.4 & 4.3 & 0.6 & 2.6 & 0.3 & 2.0 & 0.2 & 0.6 & 0.1 & 0.5 & 0.1 \\
\hline Soil & Bt1 & $10-30$ & 42.7 & 135.8 & 8.2 & 29.9 & 4.2 & 0.6 & 2.8 & 0.3 & 1.6 & 0.2 & 0.6 & 0.1 & 0.5 & 0.1 \\
\hline Soil & Bt2 & $30-70$ & 46.4 & 132.9 & 9.8 & 35.0 & 5.4 & 0.7 & 2.7 & 0.3 & 1.7 & 0.2 & 0.7 & 0.1 & 0.6 & 0.1 \\
\hline Soil & CBt2 & $70-100$ & 46.0 & 142.6 & 8.5 & 30.6 & 4.7 & 0.6 & 2.6 & 0.2 & 1.2 & 0.3 & 0.5 & 0.1 & 0.5 & 0.1 \\
\hline Soil & C & $100-150$ & 41.8 & 77.9 & 8.9 & 33.0 & 4.9 & 0.4 & 2.4 & 0.2 & 1.0 & 0.2 & 0.5 & 0.1 & 0.4 & 0.1 \\
\hline Saprolithic layer & Cr1C & $150-230$ & 52.3 & 67.7 & 11.6 & 45.1 & 6.1 & 0.9 & 3.7 & 0.3 & 1.7 & 0.3 & 0.6 & 0.1 & 0.6 & 0.1 \\
\hline \multirow[t]{2}{*}{ Saprolithic layer } & $\mathrm{Cr} 1$ & $230-350$ & 104.3 & 55.3 & 22.9 & 74.2 & 9.8 & 1.4 & 5.8 & 0.7 & 2.9 & 0.4 & 1.1 & 0.2 & 0.9 & 0.2 \\
\hline & $\mathrm{Cr} 2$ & 400 & 7.4 & 1.7 & 6.2 & 5.7 & 5.2 & 3.1 & 4.3 & 3.7 & 3.4 & 2.9 & 2.4 & 3.1 & 2.5 & 2.1 \\
\hline Rock & $\mathrm{R}$ & 500 & 203.7 & 74.7 & 35.0 & 104.8 & 14.9 & 2.4 & 9.8 & 1.4 & 6.1 & 1.1 & 2.3 & 0.3 & 1.7 & 0.2 \\
\hline \multicolumn{17}{|c|}{ P3 } \\
\hline Soil & A & $0-15$ & 121.3 & 223.5 & 23.0 & 96.0 & 18.8 & 2.6 & 16.7 & 2.1 & 13.2 & 2.3 & 7.7 & 0.9 & 5.7 & 0.7 \\
\hline Soil & $\mathrm{Bt}$ & $15-80$ & 106.8 & 180.4 & 21.8 & 90.5 & 19.0 & 3.4 & 16.7 & 2.3 & 13.2 & 2.2 & 7.0 & 0.8 & 5.9 & 0.6 \\
\hline Soil & $\mathrm{BtC}$ & $80-160$ & 95.0 & 190.9 & 19.6 & 83.9 & 17.7 & 3.0 & 14.7 & 2.0 & 12.4 & 1.9 & 7.2 & 0.8 & 6.1 & 0.7 \\
\hline Soil & C & $160-210$ & 67.3 & 154.5 & 14.1 & 60.9 & 11.8 & 2.6 & 11.7 & 1.6 & 9.5 & 1.6 & 5.4 & 0.6 & 4.1 & 0.5 \\
\hline Saprolithic layer & $\mathrm{Cr}$ & $210-250$ & 191.5 & 287.3 & 37.8 & 124.9 & 25.0 & 1.3 & 19.4 & 3.7 & 20.5 & 4.2 & 10.6 & 1.5 & 9.6 & 1.4 \\
\hline Rock & $\mathrm{R}$ & 500 & 120.5 & 231.6 & 27.4 & 93.0 & 15.8 & 2.1 & 11.4 & 2.2 & 12.6 & 2.6 & 7.1 & 1.1 & 7.0 & 1.1 \\
\hline
\end{tabular}

REE: La = Lanthanium; $\mathrm{Ce}=$ Cerium; $\mathrm{Pr}=$ Praseodymium; $\mathrm{Nd}=$ Neodymium; Sm = Samarium; Eu = Europium; Gd = Gadolinium; $\mathrm{Tb}=\mathrm{Terbium} ; \mathrm{Dy}=\mathrm{Dysprosium} ; \mathrm{Ho}$ $=$ Holmium; $\mathrm{Er}=$ Erbium; $\mathrm{Tm}=$ Thulium; $\mathrm{Yb}=$ Ytterbium; Lu = Lutetium.

than the airborn particles deposited on the surface of P3, although this last process did displace the line of the A horizon from the lines of the $\mathrm{Bt}, \mathrm{BtC}$ and $\mathrm{C}$ horizons (Figure 5).The general pattern of REE, therefore, helped to identify alloctonism in P2 and P3.

The P1 had the greatest depletion in the horizons $\mathrm{A}, \mathrm{Bt} 1 \mathrm{~A}$ and $\mathrm{Bt} 1$, the ones closest to the surface. Depletion factors decreased towards the deeper horizons and layers, as would be expected in an autigenic profile, mainly due to extraction by plants, leaching and possibly lateral elution. In P2 and P3, the horizons closest to the surface were enriched in REE, in accordance with the input processes observed.

In profile $\mathrm{P} 1$ and $\mathrm{P} 2$, Ce had positive anomaly in near surface horizons (Bt1 and above in P1 and CBt2 and above in P2) (Figure 6). In P1 this was so because absolute concentration of $\operatorname{Pr}$ was smaller than in the deeper profiles. In P2, Ce was really enriched from A to $\mathrm{CBt} 2$ (in absolute concentration), but in $\mathrm{Cr} 1, \mathrm{La}$ and Pr were higher, and even higher in Cr2. This pattern relates to the high REE total content of these layers, but particularly in $\mathrm{Cr} 2$, which was discussed before as a possible mafic band in the parent rock, enriched in HREE. The Ce anomaly in Cr2 is the most negative (0.25) of all studied samples. In P3 the Ce anomaly slightly fluctuated around 1 . This may be related to the smaller degree of development of this profile as inferred from total depth, number of horizons and WIP and CIA (Figure 6).

The Eu anomaly was positive in $\mathrm{P} 1$ (in $\mathrm{C}, \mathrm{Cr} 1, \mathrm{Cr} 2$ and $\mathrm{RCr} 2$ ) and depleted in P2 and P3 (Figure 6). The enrichment of $\mathrm{Eu}$ in $\mathrm{P} 1$ was caused by the occupancy of a number of $\mathrm{Ca}^{2+}$ structural positions by $\mathrm{Eu}^{2+}$ in plagioclases (McLennan, 1989), which is in accordance with parallelism between the $\mathrm{Eu}$ and $\mathrm{Ca}$ absolute concentrations (Table 1 and Table 2). The positive $\mathrm{Eu}$ anomaly from $\mathrm{Bt} 1$ down is related to existence of plagioclase grains in various degrees of preservation (see optical microscopy description above) (Philpotts and Schnetzler, 1970), as has also been reported in the literature (Caspari et al., 2006; Aubert et al., 2001; Compton et al., 2003; Silva et al., 2016; Galán et al., 2007). In P2 the $\mathrm{Eu}$ anomaly fluctuated around 0.5, dominantly depleted. The input of allochtone material in surface horizons are not perceived here. In the P3, $\mathrm{Eu}$ anomaly fluctuated lightly around 1, without being 
Profile P1
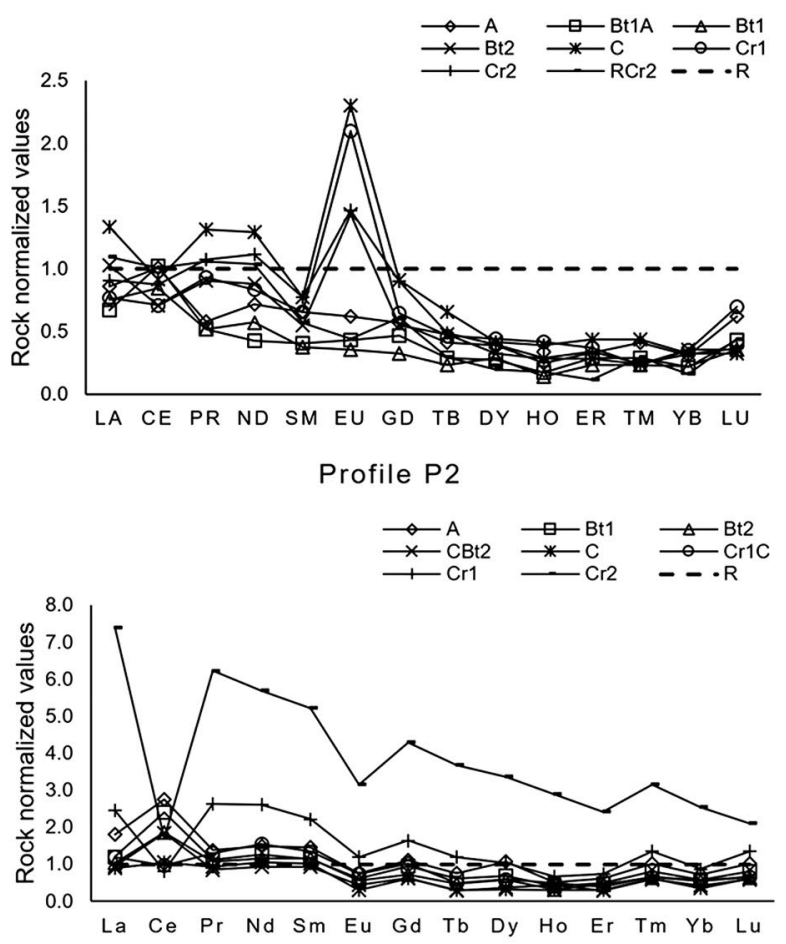

Profile P3

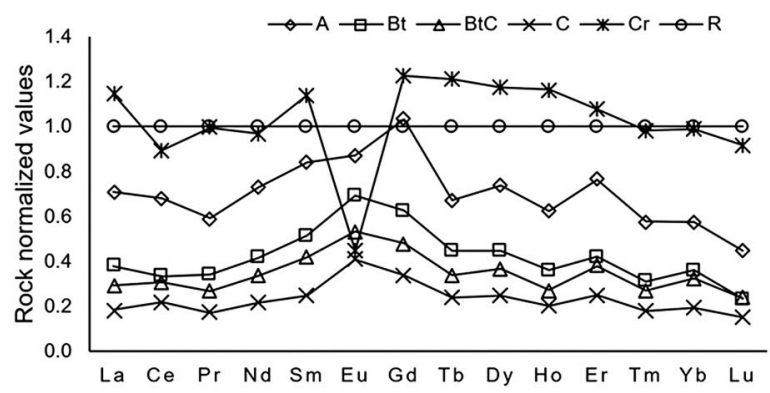

Figure 5 - Normalized values (by parent rock) of regolith profiles $P 1$, P2 and P3. (Horizons = A, Bt1, Bt2, etc.; REE: La = Lanthanium; $\mathrm{Ce}=$ Cerium; $\mathrm{Pr}=$ Praseodymium; $\mathrm{Nd}=$ Neodymium; $\mathrm{Sm}=$ Samarium; Eu = Europium; Gd = Gadolinium; Tb = Terbium; Dy $=$ Dysprosium; $\mathrm{Ho}=$ Holmium; $\mathrm{Er}=$ Erbium; $\mathrm{Tm}=$ Thulium; $\mathrm{Yb}=$ Ytterbium; Lu = Lutetium).

pronounced positive or negative, except in $\mathrm{Cr}$ where it was less than 0.5. At first, contrasting anomalies between the profiles should be expected due to the sharp increases in Gd values from P1 to P3 (discussed ahead) because $\mathrm{Gd}$ is the part of the numerator of the $\mathrm{Eu}$ anomaly formula (Equation 5, Materials and Method section). However, normalization by the parent rock, instead of an external reference, smoothed this contrast between the profiles.

Another index used to characterize the REE pattern in profiles is fractionation, which is the ratio
Anomalies - Profile P1

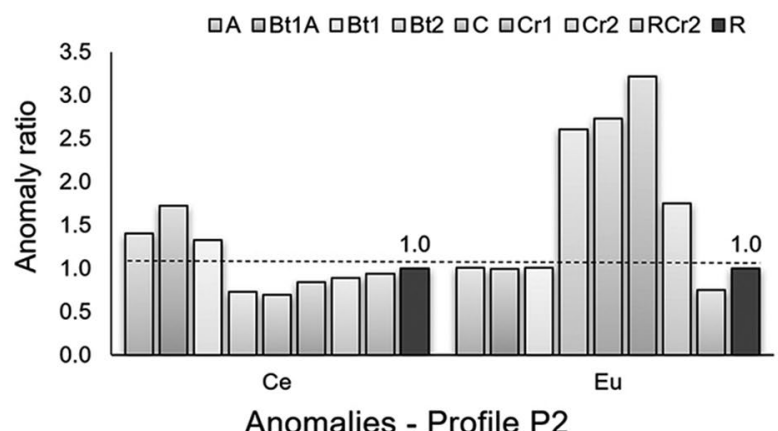

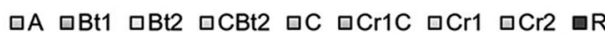

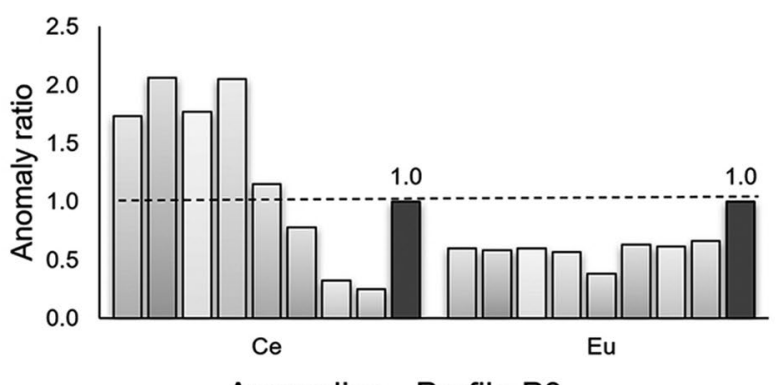

Anomalies - Profile P3

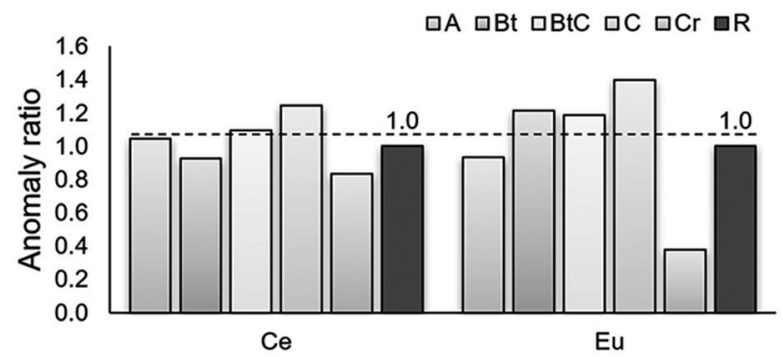

Figure 6 - $\mathrm{Ce}$ and Eu anomalies in regolith profiles P1, P2 and P3. (Horizons = A, Bt1, Bt2, etc.; $\mathrm{Ce}=$ Cerium; $\mathrm{Eu}=$ Europium).

between the LREE and HREE, or the ratio La/Yb (Figure 7). This ratio was variable and had greater values in P1. Variability was associated with the high and uneven distribution of Eu along the $\mathrm{P} 1$ that, as discussed, is driven by the plagioclase and its weathering status, and the great LREE/HREE ratio is due to the small amount of HREE in P1. The sum of normalized HREE values of all 9 horizons + layers of P1 was $28.57 \mathrm{mg} \mathrm{kg}^{-1}$ while in P3, with only 6 horizons + layers was $29.85 \mathrm{mg} \mathrm{kg}^{-1}$, because HREE are more abundant in heavy, mafic minerals. In P3 variability was low and the general content was also low, possibly due to the smaller degree of weathering/pedogenesis of this profile (smaller CIA in $\mathrm{P} 3$ than in $\mathrm{P} 2$ ). The alternative use of the $\mathrm{La} / \mathrm{Yb}$ ratio to express the fractionation was much more variable than the LREE/HREE ratio, making it more difficult to perceive a general pattern of distribution of REE in the profiles. 
Table 2 - Elementary composition of soil-saprolite profiles derived from gneisses in the southeastern region of Brazil.

\begin{tabular}{|c|c|c|c|c|c|c|c|c|c|c|c|}
\hline Zone & Horizon/Layer & Depth & $\mathrm{SiO}_{2}$ & $\mathrm{Al}_{2} \mathrm{O}_{3}$ & $\mathrm{CaO}$ & $\mathrm{Fe}_{2} \mathrm{O}_{3}$ & $\mathrm{~K}_{2} \mathrm{O}$ & $\mathrm{MgO}$ & $\mathrm{Na}_{2} \mathrm{O}$ & $\mathrm{P}_{2} \mathrm{O}_{5}$ & $\mathrm{TiO}_{2}$ \\
\hline & & $\mathrm{cm}$ & & & & & $-\%-$ & & & & \\
\hline \multicolumn{12}{|c|}{ P1 } \\
\hline Soil & A & $0-20$ & 78.67 & 11.28 & 0.50 & 0.74 & 3.13 & 0.13 & 1.44 & 0.014 & 0.10 \\
\hline Soil & Bt1A & $20-40$ & 78.65 & 13.49 & 0.43 & 0.83 & 3.37 & 0.13 & 1.53 & 0.007 & 0.10 \\
\hline Soil & Bt1 & $40-70$ & 77.39 & 14.91 & 0.38 & 0.79 & 3.23 & 0.12 & 1.48 & 0.005 & 0.09 \\
\hline Soil & Bt2 & $70-110$ & 79.36 & 14.83 & 0.48 & 0.73 & 1.51 & 0.10 & 1.74 & 0.005 & 0.07 \\
\hline Soil & C & $110-140$ & 76.64 & 15.49 & 0.42 & 1.09 & 3.37 & 0.15 & 1.52 & 0.005 & 0.13 \\
\hline Saprolithic layer & Cr1 & $140-220$ & 75.80 & 15.02 & 0.64 & 1.33 & 3.55 & 0.10 & 3.37 & 0.002 & 0.10 \\
\hline Saprolithic layer & Cr2 & $220-320$ & 75.58 & 14.68 & 0.66 & 1.62 & 3.48 & 0.17 & 3.58 & 0.007 & 0.16 \\
\hline Rock & $\mathrm{RCr} 2$ & 400 & 76.06 & 13.38 & 1.12 & 1.32 & 2.81 & 0.17 & 4.96 & 0.007 & 0.12 \\
\hline Rock & $\mathrm{R}$ & 500 & 76.55 & 12.57 & 1.23 & 1.39 & 3.52 & 0.20 & 4.34 & 0.023 & 0.11 \\
\hline \multicolumn{12}{|c|}{ P2 } \\
\hline Soil & A & $0-10$ & 77.87 & 12.49 & 0.11 & 2.45 & 1.92 & 0.30 & 0.06 & 0.027 & 0.31 \\
\hline Soil & Bt1 & $10-30$ & 78.51 & 13.96 & 0.03 & 2.79 & 1.84 & 0.23 & 0.04 & 0.016 & 0.36 \\
\hline Soil & Bt2 & $30-70$ & 76.87 & 15.70 & 0.01 & 3.06 & 1.82 & 0.25 & 0.04 & 0.016 & 0.39 \\
\hline Soil & CBt2 & $70-100$ & 76.60 & 16.36 & 0.01 & 2.92 & 2.11 & 0.35 & 0.04 & 0.011 & 0.42 \\
\hline Soil & C & $100-150$ & 76.64 & 15.99 & 0.01 & 2.47 & 2.95 & 0.59 & 0.05 & 0.011 & 0.38 \\
\hline Saprolithic layer & Cr1C & $150-230$ & 77.51 & 15.49 & 0.01 & 2.47 & 2.67 & 0.49 & 0.05 & 0.014 & 0.37 \\
\hline \multirow[t]{2}{*}{ Saprolithic layer } & Cr1 & $230-350$ & 78.36 & 15.29 & 0.01 & 2.36 & 2.95 & 0.56 & 0.06 & 0.021 & 0.31 \\
\hline & Cr2 & & & & & & & & & & \\
\hline Rock & $\mathrm{R}$ & 500 & 74.77 & 12.30 & 1.12 & 3.05 & 3.05 & 1.46 & 3.80 & 0.027 & 0.37 \\
\hline \multicolumn{12}{|c|}{ P3 } \\
\hline Soil & A & $0-15$ & 64.01 & 11.90 & 0.98 & 9.09 & 3.57 & 1.31 & 0.90 & 0.149 & 1.58 \\
\hline Soil & $\mathrm{Bt}$ & $15-80$ & 61.16 & 15.29 & 1.14 & 12.87 & 2.37 & 1.53 & 0.71 & 0.142 & 2.25 \\
\hline Soil & BtC & $80-160$ & 61.59 & 16.38 & 0.76 & 13.25 & 2.23 & 1.39 & 0.70 & 0.140 & 2.12 \\
\hline Soil & C & $160-210$ & 56.60 & 17.42 & 1.54 & 15.71 & 1.53 & 1.97 & 1.12 & 0.174 & 2.78 \\
\hline Saprolithic layer & $\mathrm{Cr}$ & $210-250$ & 75.25 & 11.77 & 0.01 & 5.22 & 5.54 & 0.70 & 0.73 & 0.073 & 0.63 \\
\hline Rock & $\mathrm{R}$ & 500 & 73.98 & 9.99 & 0.97 & 7.22 & 4.88 & 1.63 & 0.62 & 0.062 & 0.58 \\
\hline
\end{tabular}

The values of the LREE/HREE ratio were high, ranging from 7.4 to 9.2 for $\mathrm{P} 1$; from 24.8 to 42.3 for P2; and from 8.6 to 9.8 for P3 (Figure 7). A tendency of increase in the LREE/ HREE ratio in soil-saprolite profiles was observed, particularly in P1 and P2 possibly due to weathering and to the lesser mobility of LREE in comparison to HREE (Laveuf et al., 2008; Beyala et al., 2009; Cao et al., 2016). In P3, this effect was not apparent, possibly due to the great amount of REEs in the parent material. Thus, the profile development might not have been sufficient to manifest this tendency.

\section{Weathering indexes and REE}

The REE increases at depth of the soil profile not only because it was close to their source, the parent material, but also due to translocation of these elements into the soil profile and accumulation at deeper layers (Laveuf et al., 2008). This demonstrates that, despite the influence of mineralogy on distribution of these elements, REE were mobilized during the weathering process of these gneisses. Aubert et al. (2001) and Nesbitt and Markovics (1997) reported similar patterns in which weathering led to the depletion of REE in the soil surface and accumulation in deeper layers of profiles. This pattern agrees with the weathering indexes CIA and WIP (Figure 7). These indexes were approximately mirrored because the way elements are computed (see Materials and Methods section). According to these weathering indexes, the elemental changes were pronounced at the saprolite-soil boundary in $\mathrm{P} 1$ and $\mathrm{P} 3$, and at the rocksaprolite boundary in P2. The CIA pattern along the profile resembled that of the the LREE/HREE ratio in $\mathrm{P} 1$ and P2.

Gadolinium had a peculiar concentration because it was smaller than $2 \mathrm{mg} \mathrm{kg}^{-1}$ in P1, between 2 and $10 \mathrm{mg}$ $\mathrm{kg}^{-1}$ in $\mathrm{P} 2$ and greater than $10 \mathrm{mg} \mathrm{kg}^{-1}$ in P3, that is, no overlapping values and a reasonably great concentration in P3. Reference concentrations of Gd are $4 \mathrm{mg} \mathrm{kg}^{-1}$ in the UCC (Laveuf and Cornu, 2009), and from 0.26 to $5.2 \mathrm{mg} \mathrm{kg}^{-1}$ for other reference materials (Henderson, 1984). Recent papers report Gd absolute concentration such as 0.34 to $6.72 \mathrm{mg} \mathrm{kg}^{-1}$ in the Krudum granitc body (René, 2018), 9.7 to $35 \mathrm{mg} \mathrm{kg}^{-1}$ in an S-type granite in south China (Fu et al., 2019) and 0.13 to $8.16 \mathrm{mg} \mathrm{kg}^{-1}$ in chlorite-Schist in Cameroon (Onana et al., 2016). Absolute concentrations of Gd in P3 varied from 11.4 to $19.4 \mathrm{mg} \mathrm{kg}^{-1}$ (Table 1), which may relate to the presence of one or both of the dimorphs monazite and xenotime (Clark, 1984; Ni et al., 1995). These are ubiquitous $\mathrm{REE}$ phosphates (general formula $\mathrm{REE}+\mathrm{Y}\left(\mathrm{PO}_{4}\right)$ ) and Vasconcelos et al. (2018) sampled 5 xenotime cristals containing from 10800 to $26500 \mathrm{mg} \mathrm{kg}^{-1}$ of $\mathrm{Gd}$, which 

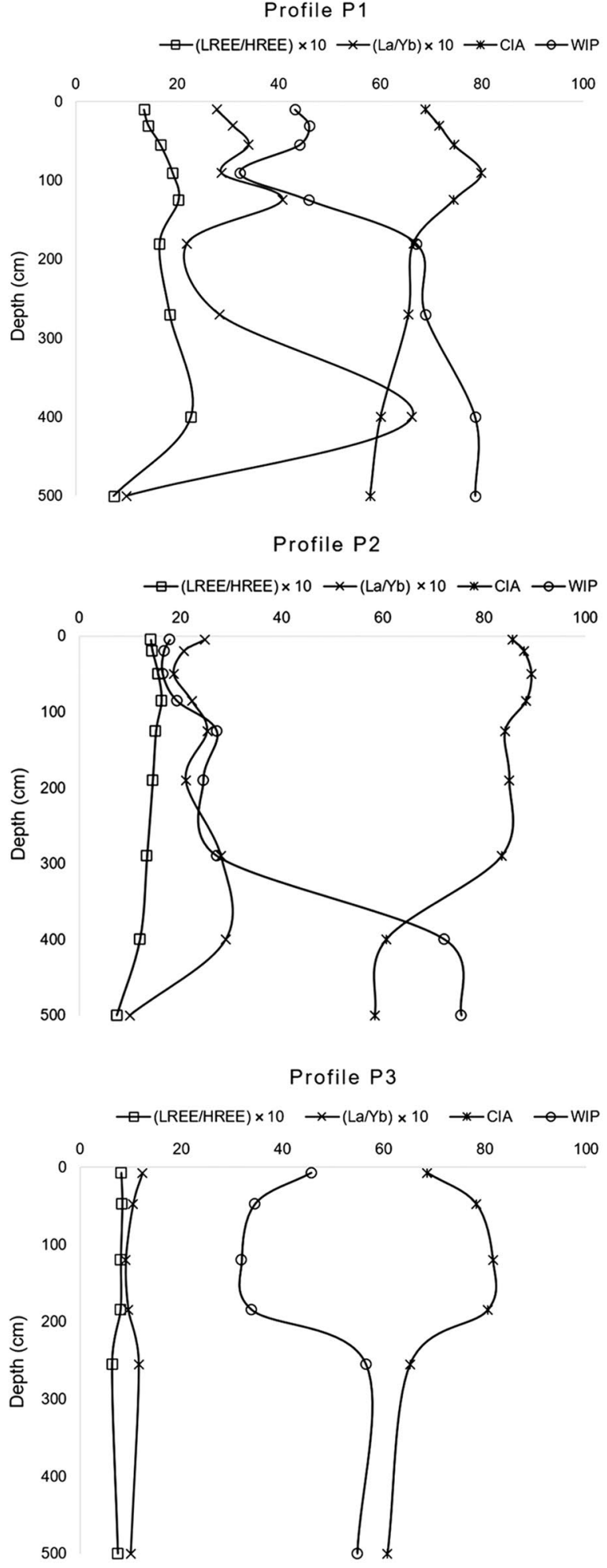

Figure 7 - REE fractionation and weathering indexes in regolith profiles P1, P2 and P3. (LREE = Light Rare Earth Elements; HREE = Heavy Rare Earth Elements; $\mathrm{CIA}=$ Chemical Index of Alteration; WIP = Weathering Index of Parker; La = Lanthanium; $\mathrm{Yb}=$ Ytterbium). relate to a 1.2 to $3.0 \% \mathrm{Gd}_{2} \mathrm{O}_{3}$ substitution for $\mathrm{Y}_{2} \mathrm{O}_{3}$. Unfortunately, we did not find xenotime crystals in the present samples, as opposed to our previous paper on gnessic profiles in NE Brazil (Santos et al., 2019a).

\section{Conclusions}

The absolute content of REE was sensitive to the mineralogical composition of horizons and layers. The mafic minerals were enriched in REE and therefore melanocratic gneiss had the greatest REE content among all profiles. At the interface between soil and saprolite transition, in leucocratic P1, the sum of absolute REE content was greater in soil than in saprolite, while the opposite pattern was observed in P2 and P3. Comparing the sums of absolute REE in the whole profiles, there was no overlap between the values of leucocratic (P1) and mesocratic (P2) gneisses, and a small overlap between mesocratic and melanocratic (P3) gneisses. A better differentiation was obtained using Gadolinium (Gd) absolute concentration, which differentiated the three gneisses in each and every horizon/layer of their regoliths without overlapping values. The Gd absolute concentration roughly paralleled the $\mathrm{P}$ concentration, but the presence of xenotime or monazite (REE phosphates) was not confirmed. Normalized REE content was useful for identify additions of materials (colluvial and airborne) to the soil surface (P2 and $\mathrm{P} 3)$. The great normalized content in the $\mathrm{Cr} 2$ of $\mathrm{P} 2$ is possibly a mafic band into the mesocratic gneiss. The Ce anomalies were positive for P1 (dominantly by leaching) and P2 (by of alloctonous material, in addition to leaching). Anomaly of Eu was greatest in P1 because of its greater content in Plagioclase. The fractionation had less variation when estimated by LREE/HREE than by $\mathrm{La} / \mathrm{Yb}$, because the variation in REE is great in gneisses (due to the segregation of minerals into bands), and had low association with weathering indexes CIA and WIP.

\section{Acknowledgements}

To CNPq (grant 305725/2012-2 to ACA; grant 202362/2013-2 to ARG) and FAPESP (Project grant 2013/03703-2).

\section{Authors' Contributions}

Conceptualization: Azevedo, A.C.; Guerra, A.R.; Ferreira, E.P. Data acquisition: Guerra, A.R. Data analysis: Azevedo, A.C.; Guerra, A.R.; Ferreira, E.P. Design of methodology: Guerra, A.R.; Ferreira, E.P. Writing and editing: Azevedo, A.C.; Ferreira, E.P.

\section{References}

Aide, M.; Smith-Aide, C. 2003. Assessing soil genesis by rareearth elemental analysis. Soil Science Society of America Journal 5:1470-1476. 
Alvares, C.A.; Stape, J.L.; Sentelhas, P.C.; Gonçalves, J.L.M.; Sparovek, G. 2014. Köppen's climate classification map for Brazil. Meteorologische Zeitschrift 22: 711-728.

Aubert, D.; Probst, A.; Stille, P. 2004. Distribution and origin of major and trace elements (particularly REE, $\mathrm{U}$ and $\mathrm{Th}$ ) into labile and residual phases in an acid soil profile (Vosges Mountains, France). Applied Geochemistry 19: 899-916.

Aubert, D.; Stille, A.P. 2001. REE fractionation during granite weathering and removal by waters and suspended loads: Sr and Nd isotopic evidence. Geochimica Cosmochimica Acta 65: 387-406.

Beyala, V.K.K.; Onana, V.L.; Priso, E.N.E.; Parisot, J.C.; Kodeck, G.E.E. 2009. Behaviour of REE and mass balance calculations in a lateritic profile over chlorite schists in South Cameroon. Chemie der Erde. Geochemistry 69: 61-73.

Cao, X.; Wu, P.; Cao, Z. 2016. Element geochemical characteristics of a soil profile developed on dolostone in central Guizhou, southern China: implications for parent materials. Acta Geochimica 35: 445-462.

Caspari, T. 2006. Geochemical investigation of soils developed in different lithologies in Bhutan, Eastern Himalayas. Geoderma 136: 436-458.

Clark, A.M. 1984. Mineralogy of the rare earth elements. In: Henderson, P., ed. Rare earth element geochemistry. Elsevier, Amsterdam, The Netherlands.

Compton, J.S.; White, R.A.; Smith, M. 2003. Rare earth element behavior in soils and salt pan sediments of a semiarid granitic terrain in the Western Cape, South Africa. Chemica Geology 201: 239-255.

Condie, K.C.; Dengate, J.; Cullers, R.L. 1995. Behavior of rare earth elements in a paleoweathering profile on granodiorite in the Front Range, Colorado, USA. Geochimica Cosmochimica Acta 59: 279-294.

Delvigne, J.E. 1998. Atlas of Micromorphology of Mineral Alteration and Weathering. Mineralogical Association of Canada, Ottawa, Canada.

Eberl, D.D.; Smith, D.B. 2009. Mineralogy of soils from two continental-scale transects across the United States and Canada and its relation to soil geochemistry and climate. Applied Geochemistry 24: 1394-1404.

Eberl, D.D.; Srodon, J.; Lee, M.; Nadeau, P.H. 1987. Sericite from the Silverton Caldera, Colorado: correlation among structure, composition, origin, and particle thickness. American Mineralogist 72: 914-934.

Food and Agriculture Organization [FAO]. 2015. World Reference Base for Soil Resources. FAO, Rome, Italy (World Soil Resources Reports, 106).

Fu, W.; Xiaoting, L.; Feng, Y.; Feng, M.; Peng, Z.; Yu, H.; Lin, H. 2019. Chemical weathering of S-type granite and formation of rare earth element (REE)-rich regolith in South China: critical control of lithology. Chemical Geology 520: 33-51.

Galán, E.; Fernández-Aliani, J.C.; Miras, A.; Aparicio, P.; Márquez, M.G. 2007. Residence and fractionation of rare earth elements during kaolinization of alkaline peraluminous granites in NW Spain. Clay Miner 42: 341-352.

Grazulis, S.; Chateigner, D.; Downs, R.T.; Yokochi, A.T.; Quiros, M.; Lutterotti, L.; Manakova, E.; Butkus, J.; Moeck, P.; Le Bail, A. 2009. Crystallography open database: an open-access collection of crystal structures. Journal of Applied Crystallography 42: 726-729.
Henderson, P. 1984. Rare Earth Element Geochemistry. Elsevier, Amsterdam, The Netherlands.

Hu, Z.; Haneklaus, S.; Sparovek, G.; Schnug, E. Rare earth elements in soils. 2006. Communications in Soil Science and Plant Analysis 37: 1381-1420.

Inoue, A. 1995. Formation of clay minerals in hydrothermal environments. p. 268-329. In: Velde, B., ed. Origin and mineralogy of clays. Springer, Berlin, Germany.

Jackson, M.L. 1975. Soil Chemical Analysis: Advanced Course. 29ed. University of Wisconsin, Madison, WI, EUA.

Jin, L.; Ma, L.; Dere, A.; White, T.; Mathur, R.; Brantley, S.L. 2017. REE mobility and fractionation during shale weathering along a climate gradient. Chemical Geology 466: 352-379.

Juilleret, J.; Dondeyne, S.; Vancampenhout, K.; Deckers, J.; Hissler, C. 2016. Mind the gap: a classification system for integrating the subsolum into soil surveys. Geoderma 264: 332-339.

Kerr, P.F. 1977. Optical Mineralogy. 4ed. McGraw-Hill, New York, NY, EUA.

Laveuf, C.; Cornu, S.; Juillot, F. 2008. Rare earth elements as tracers of pedogenetic processes. CR Geosciences 340: 523-532.

Laveuf, C.; Cornu, S. 2009. A review on the potentiality of Rare Earth Elements to trace pedogenetic processes. Geoderma 154: 1-12.

McKeague, J.A.; Day, D.H. 1966. Dithionite and oxalate extractable $\mathrm{Fe}$ and $\mathrm{Al}$ as aids in differentiating various classes of soils. Canadian Journal of Soil Science 1: 13-22.

Mehra, O.P.; Jackson, M.L. 1960. Iron oxide removal from soils and clays by a dithionite-citrate system buffered with sodium bicarbonate. Clays and Clay Minerals 7: 317-327.

Meunier, A.; Velde, B. 1982. Phengitization, sericitization and potassium-beidellite in a hydrothermally-altered granite. Clay Minerals 17: 285-299.

Meunier, A.; Velde, B. 2010. Illite. Springer, Berlin, Germany.

Ministério das Minas e Energia. 1983. Project RADAMBRASIL: Leaves SF23/24 Rio de Janeiro/Vitória: Geology, Geomorphology, Pedology, Vegetation and Potential Land Use $=$ Projeto RADAMBRASIL: Folhas SF23/24 Rio de Janeiro/Vitória: Geologia, Geomorfologia, Pedologia, Vegetação e Uso Potencial da Terra. Ministério das Minas e Energia, Rio de Janeiro, RJ, Brazil (in Portuguese).

Moore, D.M.; Reynolds, R.C. 1997. X-ray Diffraction and Identification and Analysis of Clay Minerals. 2ed. Oxford University Press, Oxford, UK.

Nesbitt, H.W.; Young, G.M. 1982. Early proterozoic climates and plate motions inferred from major element chemistry of lutites. Nature 299: 715-717.

Nesbitt, H.W.; Markovics, G. 1997. Weathering of granodiorite crust, long-term storage of elements in weathering profiles and petrogenesis of siliciclastic sediments. Geochimica Cosmochimica Acta 61: 1653-1670.

Ni, Y.; Hughes, J.M.; Mariano, A.N. 1995. Crystal chemistry of the monazite and xenotime structures. American Mineralogist 80: 21-26.

Onana, V.L.; Firmin, R.; Ntouala, D.; Tang, S.N.; Effoudou, E.N.; Kamgang, V.K.; Ekodec, G.E. 2016. Major, trace and REE geochemistry in contrasted chlorite schist weathering profiles from southern Cameroon: Influence of the Nyong and Dja Rivers water table fluctuations in geochemical evolution processes. Journal of African Earth Sciences 124: 371-382. 
Philpotts, J.A.; Schnetzler, C.C. 1970. Phenocryst-matrix partition coefficients for $\mathrm{K}, \mathrm{Rb}, \mathrm{Sr}$ and $\mathrm{Ba}$, with applications to anorthosite and basalt genesis. Geochimica et Cosmochimica Acta 34: 307-322.

Price, J.R.; Velbel, M.A. 2003. Chemical weathering índices applied to weathering profiles developed on heterogeneous felsic metamorphic parent rocks. Chemical Geology 202: 397416.

René, M. 2018. REE and Y mineralogy of the krudum granite body (Saxothuringian zone). Minerals 8: 287.

Rollinson, H.R. 1993. Using Geochemical Data: Evaluation, Presentation, Interpretation. Longman Harlow, London, UK.

Sadeghi, M.; Morris, G.A.; Carranza, E.J.M.; Ladenberger, A.; Andersson, M. 2013. Rare earth element distribution and mineralization in Sweden: an application of principal component analysis to FOREGS soil geochemistry. Journal of Geochemical Exploration 133: 160-175.

Sanematsu, K.; Kon, Y.; Imai, A. 2015. Influence of phosphate on mobility and adsorption of REEs during weathering of granites in Thailand. Journal of Asian Earth Sciences 111: 14-30.

Santos, H.G.; Jacomine, P.K.T.; Anjos, L.H.C.; Oliveira, V.A.; Lumbreras, J.F.; Coelho, M.R.; Almeida, J.A.; Cunha, T.J.F.; Oliveira, J.B. 2018a. Brazilian System of Soil Classification $=$ Sistema Brasileiro de Classificação de Solos. Embrapa Solos, Rio de Janeiro, RJ, Brazil (in Portuguese).

Santos, J.C.B.; Le Pera, E.; Souza Junior, V.S.; Oliveira, C.S.; Azevedo, A.C. 2017. Gneiss saprolite weathering and soil genesis along an east-west regolith sequence (NE Brazil). Catena 150: 279-290.

Santos, J.C.B.; Le Pera, E.; Souza Junior, V.S.; Oliveira, C.S.; Juilleret, J.; Corrêa, M.M.; Azevedo, A.C. 2018b. Porosity and genesis of clay in gneiss saprolites: The relevance of saprolithology to whole regolith pedology. Geoderma 319: 1-13.

Santos, J.C.B.; Azevedo, A.C. 2019a. Impact of weathering on REE distribution in soil-saprolite profiles developed on orthogneisses in Borborema Province, NE Brazil. Geoderma 347: 103-117.

Santos, R.A.; Sermarini, R.A.; Guerra, A.R.; Santos, J.C.B.; Azevedo, A.C. 2019b. Field perception zof the boundary between soil and saprolite by pedologists and its differentiation using mathematical models. Revista Brasileira Ciência de Solo 43: e0180104.
Schucknecht, A.; Matschullat, J.; Caritat, P.; Silva, J.; Melo Júnior, G.; Plebow, A.; Mello, J.W.V. 2012. Pedogeochemistry in NEBrazil - compared to Australia and Europe. Science of the Total Environment 438: 342-356.

Silva, Y.J.A.B.; Nascimento, C.W.A.; Biondi, C.M.; Straaten, P.; Júnior, V.S.S.; Silva, Y.J.A.B.; Santos, C.A. 2001. Influence of metaluminous granite mineralogy on the rare earth element geochemistry of rocks and soils along a climosequence in Brazil. Chemosphere 44: 655-661.

Silva, Y.J.A.B.; Nascimento, C.W.A.; Biondi, C.M.; Van Straaten, P.; Souza, V.S.; Ferreira, T.O. 2016. Weathering rates and carbon storage along a climosequence of soils developed from contrasting granites in northeast Brazil. Geoderma 284: $1-12$.

Silva, Y.J.A.B.; Nascimento, C.W.A.; Silva, Y.J.A.B.; Biondi, C.M.; Silva, C.M.C.A.C. 2016. Rare earth element concentrations in brazilian benchmark soils. Revista Brasileira de Ciência do Solo 40: 1-13.

Taylor, S.R.; McLennan, S.M. 1985. The Continental Crust: Its Composition and Evolution; An Examination of the Geochemical Record Preserved in Sedimentary Rocks. Blackwell, Oxford, UK.

Teixeira, P.C.; Donagema, G.K.; Fontana, A.; Teixeira, W.G. 2017. Manual of Methods for Soil Analysis = Manual de Métodos de Análise de Solos. 3ed. Embrapa Solos, Rio de Janeiro, RJ, Brazil (in Portuguese).

Vasconcelos, A.D.; Gonçalves, G.O.; Buick, L.I.S.; Karmo, L.S.; Korfu, F.; Scholz, R.; Alkimim, A.; Queiroga, G.; Nalini Junior, H.A. 2018. Characterization of xenotime from datas (Brazil) as a potential reference material for in situ U-Pb Geochronology. Geochemistry, Geophysics, Geosystems 19: 2262-2282.

Yamasaki, S.I.; Takeda, A.; Nanzyo, M.; Taniyama, I.; Nakai, M. 2001. Background levels of trace and ultra-trace elements in soils of Japan. Soil Science and Plant Nutrition 47: 755-765.

Yusoff, Z.M.; Ngwenya, B.T.; Parsons, I. 2013. Mobility and fractionation of REEs during deep weathering of geochemically contrasting granites in a tropical setting, Malaysia. Chemical Geology_349: 71-86. 